\title{
Francesco Piccolomini on Prime Matter and Extension
}

\author{
Guy Claessens \\ KU Leuven
}

\begin{abstract}
This paper examines the view held by Francesco Piccolomini (1523-1607) on the relation between prime matter and extension. In his discussion of prime matter in the Libri ad scientiam de natura attinentes Piccolomini develops a theory of prime matter that incorporates crucial elements of the viewpoint adhered to by the Neoplatonist Simplicius. The originality of Piccolomini's undertaking is highlighted by contrasting it with the ideas found in Jacopo Zabarella's De rebus naturalibus. The case of Piccolomini shows that, in order to classify early modern metaphysical theories of prime matter, the category 'prime matter as sheer dimensionality' is indispensable.
\end{abstract}

\section{Keywords}

prime matter, Francesco Piccolomini, Zabarella, extension, Simplicius, metaphysics

If the material universe is stripped down to its basic component, what is left? From the very outset, philosophy has faced the difficulty of conceiving this puzzling substrate. This primary stratum should by its very nature be undetermined and yet by its indefiniteness it cannot be properly conceptualized. In its different forms and different periods philosophy has always tried to cope with this ungraspable element within its core, ranging from the receptacle of Forms in Plato's Timaeus to the concept of prime matter within the Aristotelian tradition. In his impressive monograph Metaphysical Themes 1274-1671 Robert Pasnau sketches how the sixteenth and seventeenth century witnessed a gradual movement away from metaphysically based theories of prime matter towards a corpuscularian view. Within the metaphysical approach Pasnau distinguishes between four different views - two "extensionless theories" (Aquinas et alii) and 
two "extended theories" (Averroes et alii). ${ }^{1}$ If we zoom in on the second category, we see a further distinction between those who believe that prime matter is accidentally quantified, i.e. "extended in virtue of some superadded form", and those who assert that it is intrinsically extended, i.e. "extended by its very nature". ${ }^{3}$ Although I will argue that this scheme needs to be slightly modified, it clearly indicates the importance of the question whether or not prime matter is extended and - if so-in what manner. Even outside - or beyond - the metaphysical discourse, extensionality will appear to be a crucial feature of matter in later corpuscularian theories. ${ }^{4}$ In this article I will present the views on this subject held by the Siennese philosopher Francesco Piccolomini (15231607), professor of natural philosophy in Padua from 1565 until 1598 and well known for his controversy with Jacopo Zabarella (1533-1589). ${ }^{5}$ In the first part of this article I will expound Piccolomini's views on the relation between prime matter and extension and show how he incorporates crucial elements of the view held by the late Neoplatonist Simplicius in his commentary on Aristotle's Physics. Next, I will highlight the originality of Piccolomini's approach by contrasting it with the view developed by Zabarella, who is a clear proponent of Averroes' theory. Finally, I will argue that the unique character of Piccolomini's concept of prime matter as sheer three-dimensionality calls for a new component in Pasnau's classification of sixteenth- and seventeenth century theories of prime matter.

\section{Francesco Piccolomini}

Before holding the chair of natural philosophy in Padua from 1565 until 1598, Francesco Piccolomini taught philosophy in Siena, Macerata and Perugia. During his academic career he wrote several commentaries on Aristotle, e.g. a commentary on the De Anima in 1602, as well as works in the domain

1) Robert Pasnau, Metaphysical Themes 1274-1671 (Oxford, 2011), chapter 4 "Matter and Extension", 53-76.

2) Pasnau, Metaphysical Themes, 64.

3) Pasnau, Metaphysical Themes, 64.

4) Pasnau, Metaphysical Themes, 53.

5) On Piccolomini, see a.o. Eugenio Garin, Storia della filosofia italiana (Torino, 1978), 656661; Eckhard Kessler, 'The Intellective Soul' in The Cambridge History of Renaissance Philosophy, ed. C. Schmitt \& Q. Skinner (Cambridge, 1988), 485-534, esp. 527-530, and Sandra Plastina, 'Concordia discors: Aristotelismus und Platonismus in der Philosophie des Francesco Piccolomini' in Das Ende des Hermetismus. Historische Kritik und neue Naturphilosophie in der Spätrenaissance, Hrsg. von M. Mulsow (Tübingen, 2002), 213-234. 
of moral philosophy. ${ }^{6}$ From 1578 onwards, Piccolomini was involved in a controversy with Jacopo Zabarella on the theory of method, which led to the publication of the polemic Comes politicus pro recta ordinis ratione propugnator in 1594. Although the intellectual persona of Piccolomini is the subject of debate, ranging from crypto-Platonist to devoted Aristotelian, ${ }^{8}$ Eckhard Kessler adequately characterises him as mediating "between Aristotle and Neoplatonism, keeping to the former as long as possible but supplementing him with the latter when necessary." Piccolomini's merits in the fields of moral philosophy, psychology and methodology may have been widely acknowledged, ${ }^{10}$ his ideas in the domain of physics remain somewhat neglected.

In the works of Piccolomini, the peculiar and particular nature of prime matter (materia prima) is dealt with on several occasions. In the Academicae contemplationes (Venice, 1576), in which Piccolomini wishes to systematise and illustrate (in ordinem redigere \& illustrare) the doctrine of Platonism in order to reveal its true splendour and internal consistency (mirus consensus partium eius inter se \& splendor), ${ }^{11}$ chapters eight to eleven of book VII explicitly address the Platonic notion of matter. ${ }^{12}$ In his De rerum definitionibus

๑) See the bibliography of Piccolomini in Schmitt \& Skinner, The Cambridge History of Renaissance Philosophy, 861.

7) On the controversies between Piccolomini and Zabarella, see Garin, Storia della filosofia italiana, 656 and Nicholas Jardine, 'Keeping Order in the School of Padua: Jacopo Zabarella and Francesco Piccolomini on the Offices of Philosophy' in Method and Order in Renaissance Philosophy of Nature. The Aristotle Commentary Tradition, ed. D. DiLiscia, E. Kessler \& C. Methuen (Aldershot, 1997), 183-209.

8) See Garin, Storia della filosofia italiana, $656 \mathrm{ff}$ and Leen Spruit, Species Intelligibilis: from Perception to Knowledge. 2: Renaissance Controversies, Later Scholasticism, and the Elimination of the Intelligible Species in Modern Philosophy (Leiden, 1995), 239-40.

9) Kessler, The Intellective Soul, 528.

10) See Bruno Nardi, Saggi sull'Aristotelismo padovano dal secolo XIV al XVI (Firenze, 1958), esp. chapter 13; Kessler, 'The Intellective Soul'; Jill Kraye, 'Francesco Piccolomini', in Cambridge Translations of Renaissance Philosophical Texts. Volume 1. Moral Philosophy, ed. J. Kraye (Cambridge, 1997), 68-88, and Plastina, 'Concordia discors'.

11) Francesco Piccolomini, Academicae contemplationes (Venice, 1576), 14.

12) Piccolomini, Ac. contempl., 253 and 264. Piccolomini here combines the views of-among others-Simplicius, Alexander, Averroes, and Plotinus to form a heterogeneous whole, mostly without acknowledging his sources. Extension is only linked to (prime) matter by means of the Averroistic terms interminatas dimensiones and dimensiones coaeternas termino destitutas (cf. infra), which are not further elaborated. However, since the ultimate goal of Piccolomini's exposé in the Academicae contemplationes is to reconcile Platonism and Aristotelianism in this particular matter, these few chapters are not the appropriate place to look for Piccolomini's own ideas on the subject-matter. 
(Frankfurt, 1600), under the entry of materia, Piccolomini clearly speaks on his own behalf, ${ }^{13}$ but his definition of materia prima is rather disappointing. ${ }^{14}$ Fortunately enough, Piccolomini kindly refers the reader to his earlier work on the topic, namely the three books on prime matter in the Libri ad scientiam de natura attinentes (Venice, 1596). ${ }^{15}$ In book III Piccolomini devotes a cluster of seven chapters to the relation between prime matter and extension, which I will take as my starting point for expounding Piccolomini's point of view. ${ }^{16}$ The first five chapters (V-IX) of the third book critically examine the major theories concerning prime matter and extension, while the final two chapters provide us with the author's personal views on the matter.

\section{Prime matter and the form of body: Piccolomini's critical status quaestionis}

In chapter V (an materiae competat forma corporis, opiniones variae) Piccolomini introduces four opinions on the (possible) extension and dimensions of prime matter:

Among wise men there is great controversy on the extension and dimensions of matter. There are principally four opinions on this subject. [a] Some think that matter is essentially an uncompounded body. [b] Others [think] that it is not a body from itself, but that it is provided with a substantial form of body, which is coeval with it. [c] Certain people deny both options, and say that it is provided with dimensions that lack limits. [d] Finally, some assert that matter is not a body nor provided with the form of body nor with coeval dimensions, but that in generation and corruption everything changes but matter. ${ }^{17}$

13) Francesco Piccolomini, De rerum definitionibus (Frankfurt, 1600), 111-114.

14) Francesco Piccolomini, De rer. def., 112: "we have to define the prime matter of mortal objects by means of the definitions taken from Aristotle, which have already been put forward." The relation between prime matter and extension is only hinted at by the very brief paradox "[prime matter is] without limits, and has them" (sit terminorum expers, eisque praedita), a paradox that will be resolved later.

15) I quote from the Frankfurt-edition of 1597 (Francofurti, apud Andreae Wecheli heredes Claudium Marnium et Ioannem Aubrium), which is identical to the first edition. See Plastina, 'Concordia discors', 216 n.14.

16) Francesco Piccolomini, Libri ad scientiam de natura attinentes, 676-686.

17) Piccolomini, Ad scient. de nat., 676: "Magna inter viros sapientes est controversia de mole $\&$ dimensionibus materiae. Qua de re quatuor praecipue sunt opiniones; nonnulli enim putant materiam sui essentia esse corpus simplex. Alii, non ex se esse corpus, praeditam tamen esse forma substantiali corporis ei coaeva; quidam utrumque inficiantur, aiunt tamen, eam esse praeditam dimensionibus terminorum expertibus. Nonnulli demum aiunt materiam nec corpus esse nec praeditam forma corporis, nec dimensionibus ei coaevis, sed in rerum ortu $\&$ interitu cuncta variari praeter materiam." 
In the subsequent chapters Piccolomini will critically examine the arguments for and against these claims, before unfolding his own views in the final section of book III. Instead of going through all the individual pros and cons, I will set forth Piccolomini's description and general evaluation of the four theories mentioned above.

[a] Among those who hold the opinion that matter is an uncompounded body are, according to Piccolomini: (1) the atomists Democritus, Leucippus, and Epicurus, (2) Anaximander, the Stoics, the Cynics, the Cyrenaics, and Pericles of Lydia, who all thought that matter was an infinite body, and (3) Philoponus and Simplicius, who both asserted that matter was indefinite extension or sheer three-dimensionality. Strikingly enough, the major part of the chapter is devoted to a description of Simplicius' viewpoint, which is clearly based on Piccolomini's reading of Simplicius' commentary on Aristotle's Physics (esp. 227, 23-230, 33 and 623, 18-20). What differentiates the enmattered from the matterless is, according to Simplicius, volume and extension, which therefore should be attributed to matter. Now, Simplicius makes a clear-cut distinction between so-called indefinite, material extension ( $\delta$ ió $\sigma \tau \eta \mu \alpha$

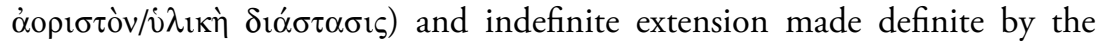

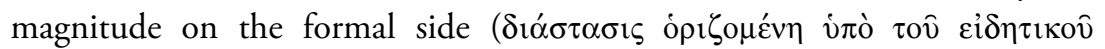
$\left.\mu \varepsilon \gamma \varepsilon \theta^{\prime} \theta \varsigma_{\varsigma}\right) .{ }^{18}$ According to Simplicius, prime matter is indefinite extension, i.e. "extension viewed separately from definite dimensions." ${ }^{19}$ As sheer threedimensionality, prime matter is a kind of indefinite body and the cause of the volume and extensionality of enmattered forms: ${ }^{20}$

So perhaps two notions of body should be postulated, the first existing in terms of form and formative principle, and made definite, by three dimensions, the second in terms of a slackening, a spreading and a lack of definiteness from the incorporeal, indivisible, intelligible reality. The second is not given a definite form by three dimensions, but is everywhere slackened, and spilt, and flows from all sides away from being into non-being. And perhaps we should postulate that matter is dimension of this sort. ${ }^{21}$

18) Simplicius, in Phys., 229, 5-7.

19) Richard Sorabji, The Philosophy of the Commentators 200-600 AD. A Sourcebook. Volume 2. Physics (London, 2004), 256.

20) Frans De Haas, John Philoponus' New Definition of Prime Matter: Aspects of its Background in Neoplatonism and the Ancient Commentary Tradition (Leiden, 1997), 121.

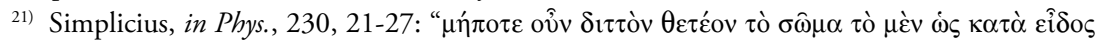

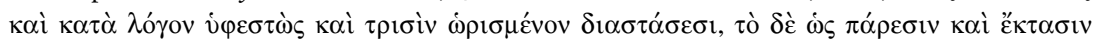

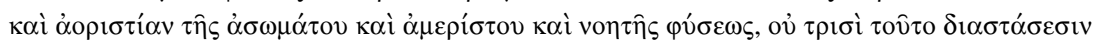

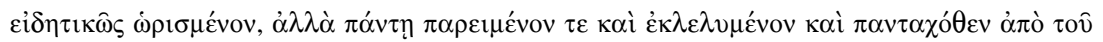


Thus, from Simplicius' perspective, definite extension is only accidentally imposed on prime matter through the introduction of form, while sheer extensionality is the essential disposition of prime matter. Nonetheless, Richard Sorabji raises an important caveat: "Simplicius' description of the extension as indefinite would mislead, if it suggested that the extension could ever exist without having definite measurements superimposed on it. What is true is only that we can think of it, without thinking of its definite measurements." 22

Piccolomini appears to faithfully reproduce the main threads of the Neoplatonist's argument: (1) extension is double, namely material and formal extension (moles materialis and formalis), ${ }^{23}$ (2) matter is material extension, (3) matter is not a body provided with three dimensions, but rather a kind of slackening and stretching out (remissio quaedam, intensio), which is by no means formally defined by three dimensions (nequaquam trina dimensione formaliter impressa ac definita). ${ }^{24}$ Next, the author contrasts Simplicius' view with that of Philoponus: the first maintains that prime matter is material quantity (quantum materiale), while the latter claims that it is formal quantity (quantum formale). ${ }^{25}$ Piccolomini probably refers to Philoponus' De aeternitate mundi contra Proclum, where it is stated that "the three-dimensional is not formless, if it is itself the form of body as such." ${ }^{26}$ As the passage from Simplicius' commentary on the Physics showed, Simplicius, unlike Philoponus, would only agree to call prime matter body in a secondary sense, ${ }^{27}$ and not "in

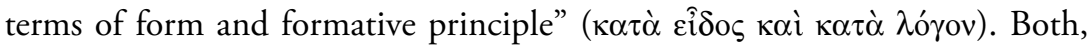
however, consent to the fact that three-dimensionality belongs to the category of substance.

In the chapter's final sentences Piccolomini stresses the fact that Simplicius' position ought not to be identified with Averroes' stance, since the latter

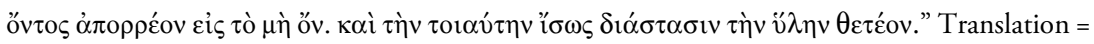
Sorabji, The Philosophy of the Commentators, 258.

22) Richard Sorabji, Matter, Space and Motion. Theories in Antiquity and Their Sequel (London, 1988), 8.

23) Prima facie, the Latin term moles may seem a strange rendering of Simplicius' (ì $\lambda_{1} \kappa \grave{n}$ )

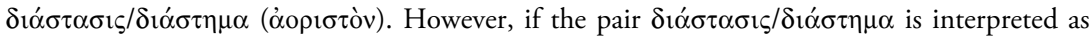
(sheer) extensionality instead of (definite) extension, the Latin moles [a shapeless, huge, heavy mass, a huge bulk] very suitably reflects Simplicius' idea of prime matter as a slackening kind of body.

24) Piccolomini, Ad scient. de nat., 677.

25) Piccolomini, Ad scient. de nat., 677.

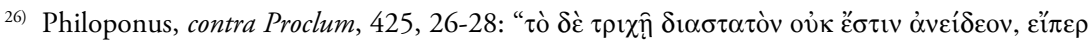

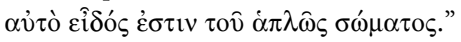

27) Sorabji, Matter, Space and Motion, 27 and Sorabji, The Philosophy of the Commentators, 265. 
denied that matter is a body, and maintained that it is provided with coeval dimensions, which are accidental and belong to a form (dimensiones materiae coaevae, quae accidentia sint \& formae). ${ }^{28}$ Averroes' theory is discussed in detail in chapter VIII (cf. infra). Although in chapter VI ( fundamenta putantium materiam esse corpus) Piccolomini offers an extensive list of arguments-taken from Aristotle-for and against the view that matter is an uncompounded body, he chooses to suspend judgment for the time being: "the arguments put forward for this opinion, and what strength they have, will be clear in its rightful place." 29

[b] The next chapter (opinio putantium materiae competere formam coaevam, quae substantia sit, \& corpus constituat quam appellant formam corporeitatis) treats the second of the theories proposed. Piccolomini rates Avicenna, Albert the Great, Suessanus (Agostino Nifo) and M. Anthonius Ianua (Marcantonio Genua) among the most important representatives of the view that matter is equipped with a coeval, substantial form of body, which precedes extensionality. ${ }^{30}$ According to Averroes in the first chapter of his De substantia orbis, Avicenna believed that prime matter is provided with a "corporeal form" (forma corporeitatis), which is the first form belonging to it. ${ }^{31}$ In Averroes' opinion-as we shall see-this corporeal form coincides with three-dimensionality. For Avicenna, on the contrary, the corporeal form is a substantial form ${ }^{32}$ and therefore cannot be identical with dimensionality, which is an accident in the category of quantity. Rather, the substantial corporeal form is the disposition to receive dimensions, and inheres in prime matter prior to dimensions. ${ }^{33}$ Avicenna's theory is immediately rejected by Piccolomini, (1) because this type of form is

\footnotetext{
28) Piccolomini, Ad scient. de nat., 677.

29) Piccolomini, Ad scient. de nat., 678-679: "Rationes autem pro ea relatae, quid roboris habeant, suo loco patebit."

30) Piccolomini, Ad scient. de nat., 679.

31) B.N. Hyman, Averroes' De Substantia Orbis: Critical Edition of the Hebrew Text with English Translation and Commentary (Massachusetts-Jerusalem, 1986), 7 and 41.

32) Or, as the medieval philosopher Moses Narboni puts it: "[...] Avicenna thinks that ,body' is a term applying to the substantiality that has the possibility that the three indeterminate dimensions [...] rest in it. This is what is meant by 'corporeity,' which is the first form existing in matter as yet undistinguished by any other form. This corporeity is not of the nature of dimension, which is an accident in the category of quantity [...]." Quoted and translated by Hyman, Averroes' De Substantia Orbis, 63-64 n.66.

33) Silvia Donati, 'The Notion of Dimensiones indeterminatae in the Commentary Tradition of the Physics in the Thirteenth and the Early Fourteenth Century', in The Dynamics of Aristotelian Natural Philosophy From Antiquity to the Seventeenth Century, ed. C.H. Leijenhorst, C. Lüthy \& M. Thijssen (Leiden, 2002), 189-223, 190.
} 
nowhere mentioned by Aristotle, and (2) due to the fact that, if prime matter would not possess dimensionality and substantial forms are indivisible, prime matter could not be divided and substantial forms could not be divisible through the division of prime matter. ${ }^{34}$ Therefore, Piccolomini writes, Avicenna's substantial form of body is a mere fiction (commentum quoddam). ${ }^{35}$

[c] At the centre of chapter VIII (de dimensionibus terminorum expertibus coaevis materiae) is Averroes, whose name has already sporadically popped up in the previous chapters:

In several places, especially in a chapter from De substantia orbis, Averroes, a man endowed with clear judgment, was of the opinion that prime matter was necessarily provided with indefinite dimensions, since he thought that it was not a body, nor that it possessed a form of body $[\ldots] .^{36}$

In the first chapter of his De substantia orbis Averroes develops his theory on the relation between prime matter and extension by distinguishing determinate from indeterminate dimensions. ${ }^{37}$ The latter only become determinate after the imposition of substantial forms and are the first thing existing in prime matter. Moreover, "prime matter is never denuded of these indeterminate dimensions" and therefore is not affected by substantial change. ${ }^{38}$ Hence, indefinite extension accounts for the divisibility of both prime matter and the substantial forms that inhere in it. As shown above, it is important to note that Averroes, unlike Avicenna, considers the corporeal form of prime matter to be an accidental form.

At first sight, Piccolomini appears to be a devoted adherent of Averroes' theory by supplying it with four additional arguments. (1) Since nature gradually progresses from imperfection to perfection, before the very first beginning of things (pro prima rerum origine) there should be a common subject provided with extensionality, which is only thereafter defined and divided. (2) Pythagoras, Plato, and Aristotle already believed that the infinite is suited

\footnotetext{
34) See Hyman, Averroes' De Substantia Orbis, 31.

35) Piccolomini, Ad scient. de nat., 681.

36) Piccolomini, Ad scient. de nat., 681: "Aver. vir acri iudicio praeditus, variis in locis, praesertim tamen in cap. de Substantia Orbis, cum putarit materiam nec corpus esse, nec praeditam forma corporis existimavit ei necessario huiusmodi indefinitas dimensiones competere [...]."

37) Averroes, De subst. orbis [Hyman], 39-73. Also see Hyman, Averroes' De Substantia Orbis, 29-35; Donati, 'The Notion of Dimensiones indeterminatae, 190-191; Robert Pasnau, Metaphysical Themes 1274-1671 (Oxford, 2011), 64-65.

38) Averroes, De subst. orbis [Hyman], 55.
} 
to matter (infinitum consentaneum esse materiae). (3) According to Aristotle, the enmattered differs from the matterless by means of extension: therefore matter is unformed and indefinite extension (rudis indefinitaque moles). (4) The necessary underlying subject of things does not change when objects originate and perish, and such is extension, which never disappears. ${ }^{39}$ Nonetheless, Piccolomini says, there is reason for doubt: (1) that which is composed of matter and form must precede that which is composed of an accident, (2) substantial form must precede accidental form, (3) a material and divisible form can never be eternal, and (4) Aristotle's definition of matter in Physics $192 \mathrm{a}^{40}$ does not relate to prime matter. ${ }^{41}$ Again, Piccolomini does not give a final opinion.

[d] In chapter IX Piccolomini introduces Aquinas and Plotinus as the two representatives of the final hypothesis, namely that prime matter is not endowed with coeval extension, neither substantially nor accidentally. According to Piccolomini, the first stated that prime matter is mere potentiality and has no corresponding actuality (materiam nec esse actum aliquem, nec ullum sibi coaevum actum exposcere), ${ }^{42}$ and the latter held the opinion that in the generation of things form brought along its corresponding extension (in rerum ortu formam secum deferre molem sibi congruentem). ${ }^{43}$ Thus, extension does not inhere in prime matter prior to form. Plotinus formulates the view as follows:

And if it [sc. matter] had magnitude, it would necessarily have figure as well; so that it would be still harder to work. So when the form comes to matter it brings everything with it; the form has everything, the magnitude and everything that goes with and is caused by the formative principle. Therefore, in every natural kind the dimensions are determined along with the form. ${ }^{44}$

\footnotetext{
39) Piccolomini, Ad scient. de nat., 681-682.

40) Aristotle, Phys., 192a31-32.

41) Piccolomini, Adscient. de nat., 682.

42) On Aquinas' views, see John D. Kronen, Sandra Menssen \& Thomas D. Sullivan, 'The Problem of the Continuant: Aquinas and Suárez on Prime Matter and Substantial Generation', The Review of Metaphysics 53/4 (2000), 863-885, John F. Wippel, The Metaphysical Thought of Thomas Aquinas. From Finite Being to Uncreated Being (Washington, 2000), chapter IX, 295-375, and David P. Lang, 'Aquinas and Suarez on the Essence of Continuous Physical Quantity', Laval Théologique et Philosophique 58/3 (2002), 565-595.

43) Piccolomini, Ad scient. de nat., 682.

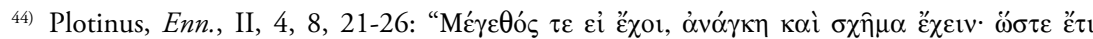

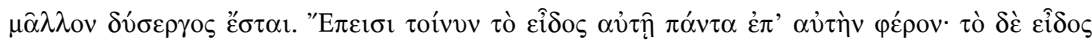

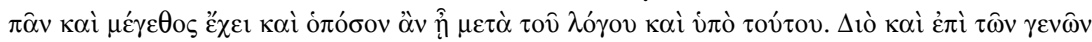

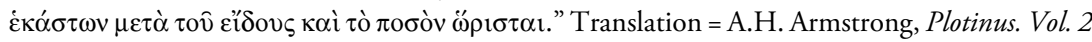
(Cambridge, MA, 1966), 125, with modifications.
} 
It does not come as a surprise that the arguments given by Piccolomini in favour of this theory largely coincide with his criticism on Averroes' stance: (1) an accident [viz. extensionality] requires a subject existing in actuality (accidens exposcit subiectum quod actu sit), (2) an enmattered and divisible form cannot be eternal (nulla forma materiata \& divisibilis valet esse aeterna), and (3) matter is in the first place the matter of substance, and only in a secondary manner the matter of accidents. ${ }^{45}$ The main argument against the fourth hypothesis is the fact that the (accidental) divisibility of substantial forms can only be accounted for by means of a primary and prior extensionality residing in prime matter-which was of course the nucleus of Averroes' argument (cf. supra $[\mathbf{c}])$.

\section{Prime matter as indefinite extensionality}

The heart of Piccolomini's discourse on prime matter and extension is found in chapter X (de mole materiae opinio propria), in which the author finally unfolds his own views, as the title of the chapter clearly states: ${ }^{46}$

\footnotetext{
Although every single one of the four main chapters on the extension of matter has appeared to be sufficiently doubtful to make me give my own view on the obscure matter, I do not promise to introduce a new opinion, but to explain clearly what I think has been the opinion of Aristotle and most of the Greeks [....$^{47}$
}

In what follows, Piccolomini will adopt Simplicius' concept of prime matter as sheer dimensionality or indeterminate extension. First of all, Piccolomini writes, two preliminary assumptions have to be made: (1) prime matter has certain dispositions (affectiones/proprietates), and (2) these properties are partly identical with their subject, namely when considered according to their absolute being (pro esse absoluto), and partly differ from it, namely when viewed extrinsically (extrinsecus), i.e. relatively. Now, according to Piccolomini, matter has two main dispositions: a potentiality towards enmattered forms (potentia ad materiatas formas), and an essential pouring out, a material dimensionality or indefinite extensionality (effusio essentialis, materiata dimen-

\footnotetext{
45) Piccolomini, Ad scient. de nat., 682.

46) Piccolomini, Ad scient. de nat., 683-684.

47) Piccolomini, Ad scient. de nat., 683: "Cum de mole materiae singula quatuor principalia capita satis dubia apparuerint, ut de re obscura proferam quod sentio, non polliceor me novam allaturum sententiam, sed eam distincte explicaturum, quam Aristotelis \& plurimorum Graecorum puto fuisse opinionem [...].”
} 
sio, sive indefinita extensio). The latter is the first subject in which the forms are received and which is subsequently bounded and limited by them. Here Piccolomini adopts Simplicius' distinction between indefinite extensionality and extension made definite by the magnitude on the formal side- which coincides with Simplicius' two notions of body:

[...] and then [i.e. when form is imposed] it [viz. indefinite extensionality] is said to be affected by formal quantity and magnitude constituted by three dimensions. Since it has this [sc. limitation] by means of any form of substance, any kind of enmattered form is said to constitute a body, and every composed [substance] owes it to form for being body in a formal manner. While bodies alternately change, material dimensionality remains and, moreover, body in general remains. ${ }^{48}$

Like Simplicius (in Phys., 537, 9-19), Piccolomini finds his theory confirmed in Aristotle's Physics 209b6-11, where the Stagirite distinguishes (indefinite) extension from definite magnitude: ${ }^{49}$

In so far as place is thought to be the extension of a magnitude, it is matter. For the extension is distinct from the magnitude; it is embraced and made definite by form, for example by a surface and contour. And that is what matter and indefinite things are like. For when the contour and passive attributes of a sphere are stripped off, nothing is left except matter. ${ }^{50}$

According to Piccolomini-once again relying on Simplicius' testimony ${ }^{51}$ Porphyry and Moderatus, a Neopythagorean of the first century AD, shared his view: they both held onto a concept of formless, undivided quantity without figure (quantitas informis, individua, figurae expers), but receptive of form, figure, and division (capax formae, figurae, divisionis). ${ }^{52}$ What is more, Piccolomini even takes over Simplicius' criticism of Alexander of Aphrodisias, namely that the latter often mistook dimension for magnitude and even reduced them to a single concept. ${ }^{53}$

48) Piccolomini, Ad scient. de nat., 683: “[...] \& tunc dicitur affici quantitate formali, \& magnitudine, ex trina dimensione constituta, $\&$ quoniam hoc habet a quavis substantiae forma, ideo quaevis materiata forma dicitur constituere corpus \& omne compositum a forma habet, ut formaliter corpus sit, dum corpora invicem permutantur, servatur materiata dimensio, insuper servatur corpus in genere." (my italics)

49) I here follow the interpretation of Sorabji, Matter, Space and Motion, 9-10.

50) Aristotle, Phys., 209b6-11. Translation = Sorabji (1988), pp. 9-10.

51) Simplicius, in Phys., 231, 5-21.

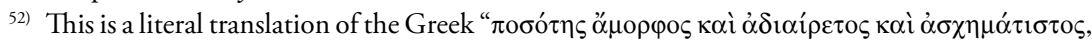

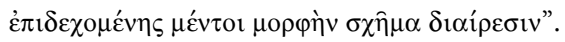

53) See Simplicius, in Phys., 538, 8ff. See Sorabji, Matter, Space and Motion, 10. 
Obviously, Avicenna's theory [b], which was "a mere fiction", is no longer mentioned by Piccolomini at this point, and the same goes for Aquinas' and Plotinus' views [d], which were countered before by means of Simplicius' and Averroes' arguments for (sheer) extensionality residing in prime matter prior to form (cf. supra [d]). There is, however, one problem with a possible integration of Averroes' viewpoint into Piccolomini's Simplicius-based theory, namely the question whether prime matter's indefinite extension is essential or accidental, or — put differently — whether prime matter essentially coincides with extensionality or not. To overcome this difficulty, Piccolomini presents an original rereading of Averroes' ideas, based on the preliminary distinction between intrinsic and extrinsic disposition introduced in the beginning of the chapter:

\begin{abstract}
Provided that it is correctly explained, Averroes' opinion on indeterminate dimensions, coeval with matter, does not differ from the opinion that has been approved: after all, indeterminate dimension, when considered as a disposition of matter intrinsically and according to its absolute being, is the essence of matter and an essential pouring out of it; yet [considered as a disposition of matter] extrinsically and from the perspective of a proper superadded form, it is an accident pertaining to quantity, which receives limits and completion by means of the form imposed. ${ }^{54}$
\end{abstract}

According to Piccolomini, the apparent contradiction between Simplicius and Averroes is only a matter of different-and even complimentary-perspectives. In fact, this "solution" merely echoes the incompatibility which it tries to overcome. Averroes' distinction between accidental-indefinite and accidental-definite extension can never be attuned to Simplicius' division between essential-indefinite and accidental-definite extension. Where Simplicius would subscribe to the opinion that definite extension is accidentally imposed through the introduction of form, Averroes would never refer to extensionality as being the essential disposition of prime matter: he can at best call it coeval. Hence, Piccolomini's self-proclaimed reconciliation of the most important authorities should be taken with a pinch of salt. ${ }^{55}$

54) Piccolomini, Ad scient. de nat., 684: "Sententia Aver. de dimensionib. interminatis, materiae coaevis, dum recte explicatur, non differt a comprobata sententia, nam dimensio interminata considerata tanquam affectio materiae, intrinsecus \& pro suo esse absoluto, est essentia materiae, \& essentialis eius effusio, extrinsecus tamen, $\&$ pro superaddita propria formalitate, est accidens ad quantitatem pertinens, quod per supervenientem formam terminos $\&$ perfectionem recipit."

55) Piccolomini, Ad scient. de nat., 684: "Sic itaque principalium authorum $\&$ interpretum sententiae satis recte conciliantur." 
For Piccolomini, three crucial questions still remain unanswered. Firstly, which one of both dispositions is prior: potentiality or extension? Evidently, Piccolomini says, extension precedes potentiality, since matter would not be able to receive forms, if it were not some kind of scattering and essential pouring out (materia non esset apta recipere formas, nisi esset dispersio o effusio quaedam essentialis). ${ }^{56}$ As shown above, this line of reasoning is based on the presuppositions (1) that the (accidental) divisibility of substantial forms can only be accounted for by means of a prior extensionality residing in prime matter, and (2) that prime matter must have extensionality before it can receive forms, to allow for the reception of more than one form at the same time. Secondly, according to Aristotle, if being is infinite, it cannot be one, since it includes both substance and quantity. ${ }^{57}$ However, in this theory matter is said to be an uncompounded and indefinite one (unum simplex \& indefinitum). Piccolomini sees a way out by distinguishing between prime matter's essential infinity - which is one and uncompounded — and actual infinity, which cannot be one. Thirdly, Aristotle's assertion that nothing can be divided in parts unless it has magnitude, ${ }^{58}$ does not tally with our opinion that matter qua essential dispersion can be divided without having magnitude. A solution similar to the previous one is provided: indeed, nothing can be divided actually unless it has magnitude, but prime matter is only potentially divisible. Prime matter becomes actually divisible through the superadded magnitude (redditur autem divisibilis actu per quantitatem supervenientem).

Although Piccolomini sometimes appears to waver indecisively between Simplicius' and Averroes' ideas, in the main his personal views seem closer to the Neoplatonist's: (1) only Averroes' position is at a certain point resolutely declined (nec dimensiones formales \& indefinitae, quae accidentia sunt sint eidem

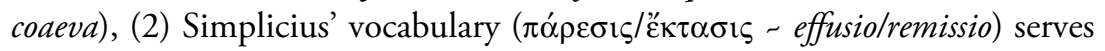
as a guideline throughout all chapters, and (3) what is actually "saved" from Averroes, namely the primordial distinction between definite and indefinite extension, perfectly links up with Simplicius' theory. Although Piccolomini remains faithful to a Thomistic perspective by emphasising prime matter's potentiality, unlike Aquinas, he puts this affectio on a par with prime matter's inherent extensionality. Now, by explicitly undermining Averroes' stance, Piccolomini not only tries to stress the self-proclaimed originality of his

\footnotetext{
56) Piccolomini, Ad scient. de nat., 684.

57) See Aristotle, Phys., 185a32-185b5.

58) See Aristotle, Phys., 204a8-12.
} 
argument, but also challenges a famous adherent of the Averroistic position: the Aristotelian philosopher Jacopo Zabarella.

\section{Jacopo Zabarella}

Although Jacopo Zabarella is nowhere mentioned in the three books on prime matter, it is hard to imagine that this long-time opponent simply had escaped Piccolomini's notice. Especially because of the fact that Zabarella had devoted two book to the subject of prime matter in his De rebus naturalibus libri XXX (posthumously published in 1590 in Venice). ${ }^{59}$ The fifteen chapters of book I respectively deal with the epistemological question how knowledge of prime matter can be attained, the relation between prime matter and privation, and matter's potentiality. Prime matter's corporeality - and the possible role of extension-is for the first time explicitly thematized in chapter 6 of the second book, where Zabarella echoes Aquinas' distinction between two types of body:

It remains to be considered whether prime matter is in itself corporeal: and since body is double - one, which is said to be the supreme kind in the category of substance; the other, which is a type of continuous quantity [...] - this consideration will therefore have two parts: the first, whether prime matter taken in itself is a body in the category of substance; the other, whether it is in itself quantitative, i.e. with length, with width, and with depth. ${ }^{60}$

59) I quote from the 1606-1607 Frankfurt edition. Jacopo Zabarella, De rebus naturalibus libri XXX (Venice, 1590), cols. 133-230. On Zabarella, see a.o. Schmitt \& Skinner, The Cambridge History of Renaissance Philosophy, 841; Eckhard Kessler, 'Zabarella, Jacopo (1533.-1589)' in Routledge Encyclopedia of Philosophy, vol. 9, ed. E. Craig (London-New York, 1998), 836-839; William A. Wallace, 'Zabarella, Jacopo' in Encyclopedia of the Renaissance, vol. 6, ed. Paul F. Grendler (New York, 1999), 337-339; Jardine, 'Keeping Order in the School of Padua', 183-209; Heikki Mikkeli, An Aristotelian Response to Renaissance Humanism: Jacopo Zabarella on the Nature of Arts and Sciences (Helsinki, 1992), and Heikki Mikkeli, 'Jacopo Zabarella (1533-1589). Ordnung und Methode der wissenschaftlichen Erkenntnis' in Philosophen der Renaissance, hrsg. von P. R. Blum (Darmstadt, 1999), 150-160.

60) Zabarella, De reb. nat., col. 191: "Considerandum manet, an prima materia per se corporea sit: \& quia duplex est corpus; unum, quod esse dicitur supremum genus in categoria substantiae; alterum, quod est species quanti continui [...]; ideo huius considerationis duae erunt partes; una, an ipsa secundum se sumpta prima materia sit corpus de genere substantiae, altera vero, an sit per se quanta, hoc est, longa, lata, ac profunda." Cf. Aquinas, De trin., q.5, a.3, ad 2: "Non enim mathematicus considerat corpus, quod est in genere substantiae, prout eius pars est materia et forma, sed secundum quod est in genere quantitatis tribus dimensionibus perfectum, et sic comparatur ad corpus quod est in genere substantiae, cuius pars est materia physica, sicut accidens ad subiectum." / "Obviously, the mathematician does not treat of the kind of body that is in the category of substance, whose parts are matter and form, but rather the body in the 
In what follows, Zabarella chooses to neglect the "ontological" order of the questions - substance is prior to quantity — and, for the sake of argumentative clarity, he begins with the second question, namely whether prime matter is a body in the category of quantity. According to Zabarella, there are two different opinions concerning this matter: (1) according to Averroes prime matter is in itself quantitatively determined by having as a perpetual accident (tamquam accidens perpetuum) indeterminate dimensions, which only become determinate through the imposition of form; (2) according to Aquinas there is no eternal quantity in prime matter, since the quantities of natural bodies follow upon forms (omnes naturalium corporum quantitates insequi formas). Hence, (determined) dimensions originate and perish as forms originate and perish.

In chapter IX Zabarella is very clear about his own point of view: Averroes is correct (quum ego veram hac in re esse putem opinionem Averrois). ${ }^{61}$ First of all, the determined quantity of objects does not follow upon matter alone, nor upon form alone, but simultaneously upon both: whereas quantity emanates as an inherent property (proprietas inhaerens) from matter, the limits of quantity are prescribed by form. In plain words: (undetermined) quantity belongs to matter, determination to form. After all, determination cannot stem from matter (nulla determinatio a materia provenire potest), nor can form determine matter unless it is received in (already) extended matter, since form in itself is neither quantitatively determined nor divisible (ipsa secundum se forma non sit quanta, nequa dividua). Surprisingly enough, Zabarella mentions Simplicius and Philoponus only once in this context and-what is more-simply portrays them as like-minded predecessors of Averroes. ${ }^{62}$ As is obvious from the foregoing, this identification of Simplicius', Philoponus' and Averroes' views is oversimplified and incorrect. ${ }^{63}$

Obviously, the question whether prime matter is a body in the category of substance is of far greater importance to Zabarella. According to Zabarella, three prevailing views should be discerned: (1) some claim that an eternal substantial form inheres in prime matter (e.g. Avicenna and Albertus), (2) some maintain that prime matter's three-dimensionality is not an accident, but its

category of quantity, constituted by three dimensions. Body, in this sense of the term, is related to body in the category of substance (of which physical matter is a part) as an accident to its subject." [Transl. Lang, 'Aquinas and Suarez on the Essence of Continuous Physical Quantity', 575] On Aquinas' view, see Ibidem, 575ff.

61) Zabarella, De reb. nat., col. 195.

62) Zabarella, De reb. nat., col. 191.

63) Cf. De Pace, Le matematiche e il mondo, 80 n.134. 
substance (Philoponus), and (3) others assert that prime matter is indeed a body in the category of quantity, but not in the category of substance (Averroes and others). Zabarella ends by adding a fourth category, i.e. his personal opinion:

\begin{abstract}
After having considered and rejected all these opinions, I will show that prime matter, in its first notion and understood in the purity of its nature, is nothing else but a body in the category of substance, not by means of that eternal form, what the first school defends, nor because it would be identical with three-dimensionality, like John the Grammarian [says]; but because according to its own nature it is an uncompounded substantial body, subject to three dimensionality $[\ldots] .^{64}$
\end{abstract}

Zaberalla's first argument runs as follows. (1) Since body (composed of matter and form) is the supreme kind in the category of substance, there needs to be a common nature participated into by all perishable bodies, by means of which all bodies can be called "body". (2) This ratio corporis is either (a) matter, (b) form, (c) a combination of matter and form, or (d) a certain accident. ${ }^{65}$ (3) It cannot be an accident, since an accident is not able to constitute a substance's essence, nor can it be form, since we have rejected the view that an eternal substantial form inheres in prime matter. The combination of matter and form cannot be the ratio corporis either. After all, those who maintain this view simultaneously deny the existence of a substantial form of body and claim that matter in itself is incorporeal. But how would it be possible that a composed corporeal thing originates from incorporeal components (ex componentibus incorporeis non potest compositum provenire corporeum) ${ }^{36}$ Moreover, the ratio or common nature of a species has to be uncompounded (simplex), which obviously precludes a combination of matter and form as ratio corporis. (4) By elimination, the ratio corporis cannot be anything but the sole nature of prime matter (sola primae materiae natura). Participation in matter is what makes $x$ a body in the category of substance. Hence, matter is not only corporeal, but a body in itself, which is said to be the supreme kind in the category of sub-

64) Zabarella, De reb. nat., col. 206: "Ego vero his omnibus sententiis consideratis, atque reiectis ostendam primam materiam in sua prima notione, $\&$ in suae naturae puritate acceptam nil aliud esse, quam corpus de categoria substantiae, non quidem per formam illam aeternam, quam prima illa secta tuetur, neque quia sit idem quod trina dimensio, ut Ioannes Grammaticus; sed quia secundum propriam suam naturam est corpus substantiale simplex, trinae dimensioni subiectum [...]."

65) Zabarella, De reb. nat., col. $215 \mathrm{ff}$.

66) Zabarella, De reb. nat., col. 215. 
stance (materia non modo corporea est, sed corpus ipsum, quod in categoria substantiae summum genus ponitur).

The second arguments proceeds in the following way. (1) Substantial body cannot exist nor be thought of without having dimensions. (2) Likewise, three-dimensionality cannot exist without a corporeal substance in which it inheres, because an accident cannot exist without a subject. (3) Obviously, incorporeal substances do not have dimensions. (4) Therefore, substantial body is that substance which is subject to three dimensions (substantiale corpus esse illam substantiam quae tribus dimensionibus subiecta est). (5) A substance without dimensions is called incorporeal, whereas a substance with dimensions is said to be corporeal. The word "body" therefore appears to denote "dimensions". For that reason (corporeal) substance is called a body in the category of substance. Here we find the heart of Zabarella's discourse:

This is —according to the order of origin — the first body in the category of substance, from which first emanates body in the category of quantity, and in which first inheres [body in the category of quantity] as its proper accident. Prime matter is the first subject of body in the category of quantity, and the latter emanates from the nature of matter itself; therefore matter itself is the first body in the category of substance. ${ }^{67}$

According to Zabarella, among the ancient philosophers, only Averroes held onto the same view and the same would go for Philoponus, if he had not maintained that prime matter is sheer three-dimensionality instead of a substance subject to dimensions. ${ }^{68}$ Nonetheless, one fundamental question remains: if prime matter is a body in the category of substance, how can it be without form? The solution provided by Zabarella is very simple: of course prime matter is not a perfect body with an actual existence (corpus perfectum

\footnotetext{
67) Zabarella, De reb. nat., col. 217: "Illud est primum corpus de categoria substantiae ordine originis, a quo primo emanat corpus de categoria quanti, \& in quo primo inhaeret tanquam proprium illius accidens; at prima materia est primum subiectum corporis de categoria quanti, idque ex ipsius materiae natura primo emanat; ipsa igitur materia est primum corpus de categoria substantiae."

68) Zabarella, De reb. nat., col. 219. Strikingly enough, both Grant and Sorabji claim that Zabarella accepted Philoponus' view, in spite of clear evidence to the contrary. See Edward Grant, 'The Principle of Impenetrability of Bodies in the History of Concepts of Separate Space from the Middle Ages to the Seventeenth Century', Isis 69/4 (1978), 551-557, 554 n.14 and Sorabji, Matter, Space and Motion, 36. Both refer to De reb. nat., col. 211, where Zabarella only adduces three arguments in favour of Philoponus' viewpoint, before refuting them in col. 213 and presenting his own view on the matter in col. 214.
} 
\& existentiae actum per se habens). ${ }^{69}$ Nevertheless, it is an indeterminate body that is only potentially determined and potentially composed: "and it is uncompounded according to its own nature, yet potentially compounded, since it is able to receive whatever form of its species, and so be assembled into whatever [form], and become a certain body."70 In the epilogue of the two books on prime matter the reader comes across a final synthesis:

For we shall say that prime matter according to its own nature is an indeterminate body in the category of substance, bound to no specific nature and able to become anything [...]. Therefore, there is no act in the nature of matter itself, but it is a kind of indeterminate substance, with the potency to receive any act. From this nature of matter two properties emanate, which are never separated from it: one is a quantity which has no limit of its own-after all, matter itself is the first root and source from which quantity and dimension in natural objects derive; the other is that universal potency to receive all forms without distinction. $^{71}$

From Zabarella's perspective, matter accounts for the corporeality of bodies and three-dimensionality only accidentally belongs to it. Only on the basis of those features prime matter can be termed 'body', i.e. as the ratio corporis and the subject of body, in the sense of dimensions. As briefly but aptly formulated by Leijenhorst: "For Zabarella, matter is a substance, existing per se. Moreover, matter is body, endowed with inherent magnitude." 72 Thus —at least concerning prime matter's relation to extension-Zabarella is a clear proponent of Averroes' theory. ${ }^{73}$ For Piccolomini on the contrary, matter is sheer three-dimensionality, without there being any relation of substance and accident between the former and the latter.

69) Zabarella, De reb. nat., col. 225.

70) Zabarella, De reb. nat., col. 226: "idque simplex secundum propriam naturam, potestate tamen compositum, quia potest quamlibet specierum suarum formam recipere, $\&$ ita ad quamlibet contrahi, \& fieri tale corpus.”

71) Zabarella, De reb. nat., col. 231: "dicemus enim, primam materiam suapte natura esse corpus de categoria substantiae indeterminatum, nulli certae naturae alligatum, \& aptum omnia fieri [...]. Ideo in ipsa materiae natura nullus actus inest, sed est substantia quaedam indeterminata, potestatem habens recipiendi quemlibet actum. Ab hac materiae natura duae proprietates emanant, quae $a b$ ipsa nunquam separantur; una est quantitas nullum secundum se terminum habens; prima enim radix $\&$ fons a quo in rebus naturalibus quantitas, ac dimensio derivatur, est ipa natura materiae: altera vero est potestas illa universalis recipiendi omnes formas indistincte."

72) Cees Leijenhorst, The Mechanisation of Aristotelianims. The Late Aristotelian Setting of Thomas Hobbes' natural philosophy (Leiden-Boston-Köln, 2002), 152.

73) Dennis Des Chene, Physiologia. Natural Philosophy in Late Aristotelian and Cartesian Thought (Ithaca-London, 1996), 384. 


\section{Conclusion: theories of prime matter and extension}

When Pasnau describes the early modern shift from a metaphysically orientated concept of prime matter towards a corpuscularian view, he divides the traditional, metaphysical approach into four views, all centred around the question whether or not prime matter is extended. In the light of the present argument the so-called "extended theories" deserve closer attention. Pasnau opposes (1) those who believe that prime matter is accidentally quantified, i.e. "extended in virtue of some superadded form", ${ }^{74}$ and (2) those who assert that prime matter is intrinsically extended, i.e. "extended by its very nature" ${ }^{75}$

Now, a problem arises when we try to incorporate Piccolomini's ideas into Pasnau's schedule. Prima facie, we would label Piccolomini's theory 'intrinsically extended'. Remarkably enough, Pasnau puts Zabarella in this category: "he [sc. Zabarella] announces that matter is a body in its own right-or, in other words, that matter, prior to form, is extended." " However, as is obvious from the above, for Zabarella prime matter is only a body in the category of substance because it is the subject of body in the category of quantity. Ontologically, the latter is accidental to the former. Indeed, the link between prime matter and extensionality is fundamental, but no more than is also indicated by the Averroistic qualification "coeval". According to Pasnau, the category 'intrinsically extended matter' further includes the Jesuit natural philosopher Benedictus Pereira and William of Ockham. ${ }^{77}$ From Pereira's point of view, extensionality is indeed a coeternal feature of prime matter, but prime matter is undoubtedly prior to quantity, since it is the latter's subject (constat autem materiam esse secundum naturam priorem quantitatem, cum sit subiectum eius). ${ }^{78}$ Like Zabarella, Pereira does not distinguish between the views of Averroes, Simplicius and Philoponus, ${ }^{79}$ while the vocabulary used by the Jesuit clearly points in the direction of the first. ${ }^{80}$ According to Ockham, prime matter is indeed intrinsically extended, but has a determinate quantity. ${ }^{81}$

Piccolomini's ideas on the subject matter clearly differ from both Zabarella's, Pereira's and Ockham's. After all, according to Piccolomini (1) extensionality is

\footnotetext{
74) Pasnau, Metaphysical Themes, 64.

75) Pasnau, Metaphysical Themes, 64.

76) Pasnau, Metaphysical Themes, 68.

77) Pasnau, Metaphysical Themes, 69-70.

78) Pereira, De communibus omnium rerum naturalium principiis (Rome, 1585 [1576]), 212.

79) Pereira, De comm., 212.

80) See De Pace, Le matematiche e il mondo, 80-81.

81) William Ockham, Summula VI: 193. See Pasnau, Metaphysical Themes, 67-69.
} 
an essential disposition of prime matter, not an ontologically posterior accident, and (2) prime matter's extensionality is indeterminate. The criterion used by Pasnau in distinguishing between the two "extended theories" is whether prime matter is extended in virtue of or prior to the imposition of a superadded form. Indeed, neither Zabarella nor Pereira mentions a 'superadded form', but both do believe that prime matter is accidentally extended. Pasnau's first category would therefore better be replaced by the broader group "threedimensionality as a coeternal accident of prime matter", which would cover the views of Averroes, Zabarella and Pereira, and could be further divided into determinate (Pereira) and indeterminate (Averroes and Zabarella) extension. The case of Piccolomini shows, I think, that within the "intrinsically extended" theories a further subcategory "prime matter as sheer, indeterminate dimensionality" is indispensable, apart from Ockham's view on prime matter as determinate extension. Piccolomini therefore occupies a highly original place in the context of (late) sixteenth century theories of matter, with the caveat that he still represents a so-called metaphysical approach. 